\title{
Nutritional levels of digestible methionine + cystine to brown-egg laying hens from 50 to 66 weeks of age
}

\author{
Clauber Polese ${ }^{1}$, Ricardo Vianna Nunes ${ }^{1}$, Christiane Garcia Vilela ${ }^{2}$, Márcia Antonia \\ Bartolomeu Agustini ${ }^{1}$, Sabrina Endo Takahashi ${ }^{3}$, Valter Oshiro Vilela ${ }^{3}$, Cleverson de Souza $^{3}$, \\ Cândida Camila dos Reis ${ }^{3}$
}

\footnotetext{
1 Programa de Pós-graduação em Zootecnia, Universidade Estadual do Oeste do Paraná, Marechal Cândido Rondon-PR, 85.960-000, Brasil.

2 Curso de Zootecnia, Universidade Estadual do Oeste do Paraná, in Marechal Cândido Rondon-PR, 85.960-000, Brasil.

${ }^{3}$ Curso de Zootecnia - UTFPR, Dois Vizinhos-PR, 85660-000, Brasil.
}

\begin{abstract}
The objective of this study was to determine the requirement of digestible methionine + cystine of browneggs laying hens from 50 to 66 weeks age at the end of the first production cycle. The design was completely randomized, with 150 Brown Shaver hens, which were distributed in five treatments with six replications of five birds each. Birds received a basal diet with $2857 \mathrm{kcal} / \mathrm{kg}$ metabolizable energy and $15.97 \%$ crude protein, supplemented with $0.132 ; 0.174,0.215,0.256$ and $0.298 \%$ DL-methionine (98\%), in order to provide $0.572,0.613,0.653,0.693$ and $0.734 \%$ digestible methionine + cystine. The levels of digestible methionine + digestible cystine followed, respectively, the relations of 67, 72, 77, 81 and $86 \%$ with lysine fixed at $0.851 \%$. Feed intake, methionine + cystine intake, feed conversion per dozen eggs, egg weigth and mass, percentage of egg components, internal egg quality and weight gain were evaluated. Methionine + cystine levels showed a quadratic effect on feed conversion per dozen eggs and egg weight, a linear effect on feed conversion per kilogram of eggs and percentage of albumen. There was also a positive linear effect on yolk percentage. The methionine + cystine requirement was estimated at $0.572 \%$, corresponding to $682 \mathrm{mg}$ of digestible methionine + cystine/bird/day.
\end{abstract}

Key Words: digestible amino acid, egg quality, performance

\section{Introduction}

The current practice to reduce the cost with feeding is based on the incorporation of industrial amino acids, since they replace the traditional protein sources (Varela, 2009). Pinto et al. (2003) pointed out that this practice allows the formulation of cheaper diets with lower crude protein levels than those recommended by the tables of nutritional requirements, in addition to meeting the requirements of essential amino acids. Therefore, protein deposition depends on amino acid supplementation in both quantity and quality as well as in biological values of dietary protein (Stringhini et al., 2005; Carvalho et al., 2009).

Junqueira et al. (2006) mentioned that the intense genetic selection has produced some competitiveness between the strains of commercial laying hens and that studies on the requirements and nutritional levels are indispensable. The authors also emphasize that nutritional levels of energy and protein should be considered in the nutrition of brown-egg laying hens during the different stages of production.

Lemme (2001) reports that the profitability of animal production depends on the formulation of diets with minimum cost. So, the use of some ingredients or sources of nutrients is important due to their nutritional values, which provide higher efficiency; otherwise, nutritional and economic losses may occur.

Togashi et al. (2002) recommended levels of 0.56 and $0.58 \%$ total methionine + cystine in diets based on corn and soybean meal, containing dry yeast for brown-egg laying hens, in order to maximize productive performance and egg quality, respectively. On the other hand, Pavan et al. (2005) suggest the use of $0.71 \%$ total sulfur amino acids to optimize production and egg weight and minimize nitrogen elimination in the feces of brown-egg laying hens at the end of the first production cycle.

Jordão Filho et al. (2006) recommended diets with 0.70\% total methionine + cystine or $0.64 \%$ from digestible methionine + cystine to optimize productive and economic performance in laying hens. However, Sá et al. (2007) estimated requirement of $0.692 \%$ digestible methionine + cystine with daily intake of $793 \mathrm{mg}$ digestible methionine + cystine/bird/day.

Thus, the objective of this experiment was to determine the nutritional levels of digestible methionine + cystine for brown-egg laying hens of the Shaver Brown strain from 50 to 66 weeks of age. 


\section{Material and Methods}

The experiment was carried out at the Unit Research of Small Animals of Universidade Tecnológica Federal do Paraná - UTFPR, Campus of Dois Vizinhos - Paraná, from May to August 2009. One hundred and fifty brown-egg laying hens of the Shaver Brown strain at 50 weeks of age and $1,877.27 \pm 92.95 \mathrm{~g}$ average weight were evaluated.

The selection and distribution of laying hens in each experimental unit were performed according to body weight and egg production, based on recommendations of Sakomura \& Rostagno (2007). Hens were allotted to five treatments comprising six replications with five birds per experimental unit in a completely randomized design. Diets were fed ad libitum in trough feeders with divider and water was supplied in nipple drinkers.

During starter, growth and production phases, birds were handled as described in the respective manual of the strains. During the production phase, birds were housed in east-western cages $(50 \times 40 \times 50 \mathrm{~cm})$, arranged in a closed brick shed $(8.5 \times 20 \mathrm{~m})$, with anti-bird mesh on the sides, covered with clay tiles, with $2.80 \mathrm{~m}$ ceiling height. In the shed, there was a central corridor $(1.5 \mathrm{~m})$ with four sets of cages arranged in two overlapped rows. Birds were subjected to a $16 \mathrm{~h}$ photoperiod - 12 natural and four artificial hours of light.

A basal diet (Table 1) with the same amount of nutrients and energy was formulated to determine the nutritional requirement of digestible methionine + cystine, estimating feed intake of $110 \mathrm{~g} / \mathrm{bird} / \mathrm{day}$, except for the digestible methionine + cystine levels, supplemented with $0.132,0.174$, $0.215,0.256$ and $0.298 \%$ DL-methionine (98\%), obtaining the real tested levels of $0.572,0.613,0.653,0.693,0.734 \%$ digestible methionine + cystine. The levels of digestible methionine + cystine followed, respectively, the relations of $67,72,77,81$ and $86 \%$ with lysine fixed at $0.851 \%$. The other nutrients in the diets were met according to recommendations of Rostagno et al. (2005).

Table 1 - Composition of experimental diets

\begin{tabular}{|c|c|c|c|c|c|}
\hline \multirow[t]{2}{*}{ Ingredients } & \multicolumn{5}{|c|}{ Level of digestible methionine + cystine (\%) } \\
\hline & 0.572 & 0.613 & 0.653 & 0.693 & 0.734 \\
\hline Corn & 63.79 & 63.82 & 63.87 & 63.92 & 63.97 \\
\hline Soybean meal & 21.55 & 21.49 & 21.42 & 21.35 & 21.28 \\
\hline Limestone & 9.40 & 9.40 & 9.40 & 9.40 & 9.40 \\
\hline Soybean oil & 2.13 & 2.11 & 2.08 & 2.05 & 2.03 \\
\hline Dicalcium phosphate & 2.10 & 2.10 & 2.11 & 2.11 & 2.11 \\
\hline Salt & 0.350 & 0.350 & 0.350 & 0.350 & 0.350 \\
\hline L-lysine $\mathrm{HCl}$ & 0.212 & 0.214 & 0.217 & 0.219 & 0.221 \\
\hline Mineral and vitamin supplement ${ }^{1}$ & 0.200 & 0.200 & 0.200 & 0.200 & 0.200 \\
\hline DL-methionine & 0.132 & 0.174 & 0.215 & 0.256 & 0.298 \\
\hline L-theonine & 0.101 & 0.102 & 0.103 & 0.104 & 0.105 \\
\hline L-tryptophan & 0.0225 & 0.0230 & 0.0233 & 0.0237 & 0.0240 \\
\hline Antioxidant ${ }^{2}$ & 0.020 & 0.020 & 0.020 & 0.020 & 0.020 \\
\hline Total & 100.00 & 100.00 & 100.00 & 100.00 & 100.00 \\
\hline \multicolumn{6}{|l|}{ Calculated composition } \\
\hline Crude protein (\%) & 15.960 & 15.970 & 15.960 & 15.960 & 15.960 \\
\hline Metabolizable energy (kcal/kg) & 2857 & 2857 & 2858 & 2858 & 2858 \\
\hline Calcium (\%) & 4.210 & 4.210 & 4.210 & 4.210 & 4.210 \\
\hline Available phosphorus (\%) & 0.485 & 0.485 & 0.486 & 0.486 & 0.486 \\
\hline Sodium (\%) & 0.156 & 0.156 & 0.156 & 0.156 & 0.156 \\
\hline Potassium (\%) & 0.634 & 0.633 & 0.631 & 0.630 & 0.629 \\
\hline Digestible lysine (\%) & 0.851 & 0.851 & 0.851 & 0.851 & 0.851 \\
\hline Digestible methionine (\%) & 0.356 & 0.398 & 0.438 & 0.478 & 0.520 \\
\hline Digestible methionine + cystine (\%) & 0.572 & 0.613 & 0.653 & 0.693 & 0.734 \\
\hline Digestible threonine (\%) & 0.596 & 0.596 & 0.596 & 0.596 & 0.596 \\
\hline Digestible tryptophan (\%) & 0.174 & 0.174 & 0.174 & 0.174 & 0.174 \\
\hline Digestible valine (\%) & 0.656 & 0.655 & 0.653 & 0.652 & 0.651 \\
\hline Digestible arginine \%) & 0.920 & 0.918 & 0.916 & 0.914 & 0.912 \\
\hline Digestible leucine (\%) & 1.319 & 1.318 & 1.316 & 1.314 & 1.312 \\
\hline Digestible isoleucine (\%) & 0.574 & 0.573 & 0.572 & 0.571 & 0.569 \\
\hline Digestible histidine (\%) & 0.399 & 0.399 & 0.398 & 0.398 & 0.397 \\
\hline Digestible phenylalanine (\%) & 0.714 & 0.713 & 0.711 & 0.710 & 0.709 \\
\hline
\end{tabular}


Birds were fed diets up to 50 weeks of age as recommended by Rostagno et al. (2005). After experimental diets were supplied, the experimental period started, lasting 16 weeks,divided in four periods of data collection. Each period corresponded to 28 days, in which the following variables were evaluated: feed intake, methionine + cystine intake, feed conversion per dozen $(\mathrm{kg} / \mathrm{dz})$ and egg mass $(\mathrm{kg} / \mathrm{kg})$, laying rate (\%), egg weight (g), egg mass (g), percentage of egg components (shell, albumen and yolk), density and internal egg quality (Haugh unit, yolk index and albumen index). The weight gain was evaluated after the experimental period.

Eggs were manually collected twice a day: in the morning (11:00 am) and in the afternoon (4:00 pm). The egg laying rate was calculated based on the number of produced eggs/ bird/day. Eggs were weighed during the last three days of each period to determine the average weight or mass of eggs.

Feed intake (g/bird/day) was measured weekly. Feed intake was corrected according to bird mortality in the experimental unit. The intake of methionine + cystine in $\mathrm{mg} /$ bird/day was calculated based on the intake and the percentage of methionine + cystine. Feed conversion was calculated by the division of feed intake by the production in dozen of eggs ( $\mathrm{kg} / \mathrm{dz}$ ) and the egg mass produced $(\mathrm{kg} / \mathrm{kg})$ in each of the four periods.

The eggs were evaluated to determine specific gravity, through saline solutions with densities ranging from 1.075 to 1.095 .

Four eggs were selected ( $\pm 10 \%$ average weight) per treatment and repetition to determine their internal quality and composition. The eggs were collected in the last three days of each period: two were designed to determine the components of egg (shell percent, yolk and albumen) and the others were used to evaluate the internal quality (Haugh unit and yolk index and albumen).
The percentage of egg components was determined by weighing each egg (egg total weight), then yolk and shell were weighted. Shell was weighed after remaining 48 hours at room temperature and 8 hours under forcedventilation oven at $65^{\circ} \mathrm{C}$. The albumen weight was obtained by subtracting the egg weight integrity, minus yolk and shell weights.

Haugh units were determined according to the methodology described by Haugh (1937), while the number of yolk and albumen were obtained by the average of diameters of yolk and albumen with a digital caliper, following the methodology described by Snyder (1961). Skin thickness was measured at two different points of the meridian with a digital micrometer of $0.001 \mathrm{~mm}$ accuracy. Shell weight per unit surface area was calculated according to methodology adapted by Rodrigues et al. (1996).

The digestible methionine + cystine requirements were estimated using the variables productive performance and egg quality by analysis of variance (ANOVA) and subsequently applied to a polynomial regression analysis, considering the value of $\mathrm{R}^{2}$, through software SAEG (Sistema para Análises Estatísticas e Genéticas, version 9.1).

\section{Results and Discussion}

There was no significant effect of the levels of digestible methionine + cystine on feed intake or feed conversion per egg mass $(\mathrm{P}>0.05)$ (Table 2). However, the digestible methionine + cystine intake showed a linear increase $(\mathrm{P}<0.05)$ and followed the increasing levels of those amino acids in the diet of birds. There was a quadratic effect of the levels of digestible methionine + cystine on feed conversion per dozen eggs, estimating requirement of $0.679 \%$ digestible methionine + cystine to improve the result of this variable.

The results obtained for feed intake of laying hens are compared with those of Togashi et al. (2002). However,

Table 2 - Performance of laying hens from 50 to 66 weeks age fed diets containing different levels of digestible methionine + cystine

\begin{tabular}{|c|c|c|c|c|}
\hline Levels digestible met + cys (\%) & $\begin{array}{l}\text { Feed intake } \\
\text { (g/bird/day) }\end{array}$ & $\begin{array}{c}\text { Digestible met }+ \\
\text { cys intake (mg/bird/day) }\end{array}$ & $\begin{array}{l}\text { FC per dozen } \\
\text { eggs }(\mathrm{kg} / \mathrm{dz})\end{array}$ & $\begin{array}{c}\text { FC egg mass } \\
(\mathrm{kg} / \mathrm{kg})\end{array}$ \\
\hline 0.572 & 119.22 & 681.96 & 1.515 & 1.972 \\
\hline 0.613 & 120.45 & 738.36 & 1.567 & 1.989 \\
\hline 0.693 & 120.25 & 833.38 & 1.588 & 1.973 \\
\hline 0.734 & 119.42 & 876.57 & 1.568 & 1.959 \\
\hline Mean & 119.60 & 781.07 & 1.563 & 1.968 \\
\hline $\begin{array}{l}\text { Digestible met }+ \text { cys intake (mg/bird/day) } \\
\text { FC per dozen eggs }\end{array}$ & \multicolumn{2}{|c|}{ Regression equation } & $\begin{array}{c}\text { Requirement } \\
0.572 \\
0.679\end{array}$ & $\begin{array}{l}0.99 \\
0.97\end{array}$ \\
\hline
\end{tabular}

NS - not significant; L - linear effect; Q - quadratic effect; CV - coefficient of variation; FC - feed conversion. 
these researchers obtained feed conversion values per dozen eggs, and the egg mass reponse was superior to this study. The authors concluded that $0.56 \%$ total methionine + cystine is enough to maximize the characteristics associated to productive performance.

In a study with different protein levels (14 to 17\%) and total sulfur amino acids ( 0.57 to $0.71 \%$ ) in diets for laying hens at 52 weeks of age, Pavan et al. (2005) found no significant difference in feed intake or feed conversion per dozen and egg mass.

Jordão Filho et al. (2006) observed a linear reduction in feed intake $(\mathrm{P}<0.01)$ when evaluating the nutritional requirement of total methionine + cystine for brown-egg laying hens, as the levels of these amino acids increased $(0.61 ; 0.68 ; 0.75 ; 0.82 ; 0.89)$. According to the authors, birds can reduce the ingestion of feed to make up for the excess of amino acids in a diet, but the effect described was not observed in this study. Cupertino et al. (2009) also observed a linear increase in feed intake according to the studied levels of digestible methionine + cystine $(0.492 ; 0.544$; 0.596; 0.648 and 0.700). However, Sá et al. (2007) and Safaa et al. (2008) found no effect of different digestible methionine + cystine levels on feed intake of brown-egg birds, thus, the result obtained for feed intake by layer hens corroborates the ones obtained in this experiment.

Feed intake responses were similar between the treatments studied, which can be explained by the fact that there was no excess or imbalance of amino acids in the experimental diets, since the excess of sulfur amino acids would lead to some reduction in feed intake by birds (Goulart, 1997). Furthermore, the energy level of diets was the same, which probably contributed to keep the same feed intake.

According to Togashi et al. (2002), the advanced age of birds determines specific requirement, because there is less efficiency of feed utilization and, besides, the protein requirement cannot be anticipated based on the responses of younger birds in order to avoid the decrease in laying production of eggs, at the end of the laying period.

The levels of digestible methionine + cystine showed a quadratic effect $(\mathrm{P}=0.036)$ on feed per dozen eggs. These answers are in accordance with a study that was carried out by Togashi et al. (2002), who estimated a $0.566 \%$ demand for this variable.

On the other hand, Jordão Filho et al. (2006) observed a decrease in feed conversion per dozen eggs with increase in the levels of methionine + cystine. Cupertino et al. (2009) had already observed a linear decrease in feed conversion per dozen and egg mass as there was an increase in the levels of digestible methionine + cystine in the diet, whose values ranged from 1.65 to $1.84 \mathrm{~kg} / \mathrm{dz}$ and 2.04 to $2.38 \mathrm{~kg} / \mathrm{kg}$, respectively.

Bunchasak \& Silapasorn (2005), in a research with different protein levels (14 and 16\%), observed an improvement in feed conversion per egg mass as supplementation with methionine increased in low protein feeds for brown-egg laying hens from 24 to 44 weeks age, but this effect was not observed in the present study. Jordão Filho et al. (2006) estimated 0.69\% total methionine + cystine for better feed conversion per egg mass, which is equivalent to an intake of $751 \mathrm{mg} /$ bird/day. Sá et al. (2007) estimated $0.697 \%$ digestible methionine + cystine to obtain better feed conversion per dozen eggs, which corresponds to an intake of $778 \mathrm{mg} / \mathrm{bird} /$ day.

The improvement in feed conversion per dozen eggs obtained for the highest levels of supplementation in this experiment can be explained by better efficiency of feed utilization with an increase in the levels of digestible methionine + cystine in the diet. This is explained by the better amino acid balance, because the highest tested level (0.734\% and methionine + cystine:lysine ratio of 0.86$)$ are close to those recommended by the NRC (1994) and by Rostagno et al. (2005), 0.84 and 0.91, respectively, for brown-egg laying hens.

There was no effect of digestible methionine + cystine levels for laying rate and egg mass. There was a quadratic effect $(\mathrm{P}=0.0079)$ for egg weight, estimating requirement of $0.696 \%$ digestible methionine + cystine for hens to produce heavier eggs (Table 3).

The levels of methionine + cystine showed a quadratic effect $(\mathrm{P}=0.0079)$ over the egg weight. Togashi et al. (2002) observed the same effect for the same variable and they estimated some requirement for $0.582 \%$ total methionine + cystine. On the other hand, Sohail et al. (2002), when evaluating different levels of total sulfur amino acids and crude protein ( 0.81 and 18.05 ; 0.72 and 16.66; and 0.65 and $15.15 \%$, respectively), observed a linear increase in egg weight, as the levels of total amino acids increased in the diet of laying hens at 21 weeks of age. The authors justify the linear effect by the fact that at this age, birds have not yet reached the peak of egg production, egg weight and growth, which can be caused by higher nutritional requirement of amino acids.

Pavan et al. (2005) found no significant differences for rate of egg laying and egg mass, so the results obtained in this study corroborate those ones. Similar results were also obtained by Brake et al. (1979), Harms (1983) and Koelkebeck et al. (1993), when they worked with diets containing high 
Table 3 - Egg laying rate, weight and egg mass of hens from 50 to 66 weeks age fed diets containing different levels of digestible methionine + cystine (met + cys)

\begin{tabular}{|c|c|c|c|}
\hline Levels digestible met + cys (\%) & Laying rate $(\%)$ & Egg weight (g) & Egg mass (g) \\
\hline 0.572 & 94.12 & 64.24 & 60.46 \\
\hline 0.613 & 91.90 & 65.92 & 60.57 \\
\hline 0.653 & 91.83 & 66.27 & 60.87 \\
\hline 0.734 & 91.66 & 66.52 & 60.97 \\
\hline Mean & 92.27 & 65.86 & 60.76 \\
\hline $\mathrm{CV}(\%)$ & 2.22 & 1.66 & 2.75 \\
\hline
\end{tabular}

NS - not significant; Q - quadratic effect; CV - coefficient of variation.

and low levels of protein, respectively. Jordão Filho et al. (2006) also evaluated different levels of total methionine + cystine $(0.61 ; 0.68 ; 0.75,0.82,0.89 \%)$ for brown-egg laying hens from 20 to 44 weeks of age. They observed a linear decrease in laying rate, which ranged from 86.56 to $91.06 \%$, i.e., lower values than the ones observed in this study.

The similarities in laying rate for the levels evaluated, associated with the ones from the literature, reinforce that it is possible to work with lower levels of digestible methionine + cystine than the ones recommended by Rostagno et al. (2005), who suggest the requirement of $0.683 \%$ for layers with $1,800 \mathrm{~g}$ body weight and egg mass of $50 \mathrm{~g} / \mathrm{bird} /$ day.

Jordão Filho et al. (2006) observed a quadratic effect on egg weight and estimated $0.73 \%$ requirement of total methionine + cystine and intake of $794 \mathrm{mg} / \mathrm{bird} /$ day. The quadratic effect was similar to the one observed in this experiment for egg weight. This response was also obtained by Barbosa et al. (1999), Togashi et al. (2002), Ahmad \& Roland (2003) and Harms \& Russell (2003).

Sá et al. (2007) observed a quadratic effect of digestible methionine + cystine and also estimated a requirement of 0.669 and $0.692 \%$ for better production and egg mass with intake of 767 and $793 \mathrm{mg} /$ bird/day, respectively.

The lower egg weight obtained for the extreme levels evaluated in this experiment explains the negative effect of deficiency or excess of methionine + cystine in the diet on this variable. In this sense, Koelkebeck et al. (1991) classify methionine as the most toxic amino acid when in excess in diets for hens. It is worth stressing, also, that egg weight is not a determinant factor in poultry farming, since egg mass involves production and egg weight at the same time. Bunchasak \& Silapasorn (2005) observed that the addition of methionine in excess leads to an increase in abdominal fat deposition and verified higher production and egg weight due to an increased synthesis of estrogen at the ovary level. Carvalho et al. (2009) mention that birds can use part of protein and energy to gain weight and produce heavier eggs.

While studying different methionine + cystine:lysine ratios (0.76, 0.83, 0.85 and 0.86), Jordão Filho et al. (2006) observed better productive parameters at the ratio of 0.77 methionine + cystine: lysine for brown-egg laying hens and that this ratio meets better the nutritional requirements of birds. However, in the present study, the best ratio obtained was 0.81 for the heaviest egg weight.

The different reponses in this experiment were compared with some data in the literature and suggested that the requirement of amino acids for maximum weight, production and egg mass does not significantly reduce during the laying period. Therefore, some adjustments must be made in the levels of amino acids from the diet to make up for the changes in daily feed intake. Harms \& Russell (1998) mentioned the existence of a negative correlation between weight and egg production with the increase of methionine + cystine levels, but this effect was not observed in this study.

There was no effect from the levels of digestible methionine + cystine on the Haugh unit, yolk index or albumen index (Table 4).

Togashi et al. (2002) found quadratic effect of increasing levels of total methionine + cystine on the Haugh unit and estimated $0.558 \%$ requirement, as opposite to Pavan et al. (2005), who found no significant difference when evaluating diets with different levels of crude protein supplemented with methionine. Similarly, Sá et al. (2007) did not observe any influence from digestible methionine + cystine levels at Haugh unit, yolk index and albumen.

There was an increase in egg weight $(P=0.0079)$ with the increase in methionine + cystine intake. Furthermore, the bigger the eggs the greater was the effect of gravity on measurement of yolk and albumen height, i.e., greater were the chances to find lower height values the components of heavier eggs. These values contribute directly to the calculatin of yolk and albumen rates and the Haugh unit. 
Table 4 - Haugh unit, yolk index and albumen index of eggs from hens from 50 to 66 weeks age fed diets containing different levels of digestible methionine + cystine (met + cys)

\begin{tabular}{cccc}
\hline Digestible met + cys levels (\%) & Haugh unit & Yolk index & Albumen index \\
\hline 0.572 & 76.19 & 0.428 & 0.0728 \\
0.613 & 76.80 & 0.411 & 0.0709 \\
0.653 & 74.91 & 0.416 & 0.0690 \\
0.693 & 73.85 & 0.411 & 0.0665 \\
0.734 & 72.72 & 0.407 & 0.0689 \\
Mean & 75.49 & 0.414 & 0.0696 \\
CV(\%) & 5.54 & 4.34 & 9.52 \\
P value & NS $(P>0.05)$ & NS $(P>0.05)$ & NS (P>0.05) \\
\hline
\end{tabular}

NS - not significant; CV - coefficient of variation.

The data corroborate the results obtained by NarváezSolarte et al. (2005), who found that the internal quality parameters of the egg were not affected by the increasing levels of methionine + cystine in the diet of light and semiheavy layer hens from 22 to 38 weeks of age.

Thus, Brumano et al. (2010) mentions that several factors can affect the internal quality of egg, such as storage time, bird age, room temperature and the type of equipment used to determine several measurements, so it is common to obtain different responses in the experimental trials for parameters as the internal quality of egg.

Cupertino et al. (2009) did not observe significant effect of digestible methionine + cystine levels on the Haugh unit in egg layers from 54 to 70 weeks of age. Novak et al. (2004) also found no effect of intake levels of methionine + cystine (635 to 877 mg/bird/day) for this variable. However, NarvaezSolarte et al. (2005) observed improvement in the Haugh unit as they reduced the levels of total methionine + cystine in the diet of layer hens. There was no significant effect $(\mathrm{P}>0.05)$ on the levels of methionine + digestible cystine on specific gravity, shell thickness, shell percentage and shell weight per surface area. There was a linear effect $(\mathrm{P}<0.05)$ of the digestible of methionine + cystine levels on yolk percentage and linear decrease $(\mathrm{P}<0.05)$ in the percentage of albumen (Table 5).
The results obtained in this study reinforce those reported by Togashi et al. (2002), which indicate that the levels of total methionine + cystine did not affect the percentage of eggshell per surface area and corroborate the results obtained by Rodrigues et al. (1996), who found no differences in the shell quality when they were evaluated by shell weight per surface area.

Pavan et al. (2005) have already evaluated the different levels of crude protein and total sulfur amino acids, but there was no improvement in eggshell quality. This can be confirmed by the absence of a statistically significant difference between the levels for specific gravity and percentage of shell. Such results are similar to those ones obtained by Harms (1983), Koelkebeck et al. (1993), and Ahmad et al. (1997).

Fraser et al. (1998) pointed out that the base of egg shell consists of a protein matrix, so it is possible that the increase in the intake of sulfur amino acids can influence protein synthesis of shell membranes. However, this fact was not observed in this study, once shell weight and shell percentage were not significantly affected.

Pavan et al. (2005) recorded higher yolk percentage when they used combinations of 14 and 0.57 and 14 and $0.64 \%$ crude protein and total sulfur amino acids. However, the highest percentages of albumen were obtained for the

Table 5 - Specific gravity, shell thickness and yolk percentage of shell and albumen of eggs from hens from 50 to 66 weeks age fed different levels of digestible methionine + cystine

\begin{tabular}{|c|c|c|c|c|c|c|c|}
\hline$\overline{\text { Digestible }}$ & met + cys levels $(\%)$ & Specific gravity & Shell thickness (mm) & Yolk (\%) & Shell (\%) & Albumen (\%) & SWSA $\left(\mathrm{mg} / \mathrm{cm}^{2}\right)$ \\
\hline & 0.572 & 1.0904 & 0.450 & 25.67 & 9.85 & 64.48 & 84.90 \\
\hline & 0.613 & 1.0903 & 0.445 & 26.11 & 9.84 & 64.06 & 85.20 \\
\hline & 0.653 & 1.0904 & 0.452 & 25.37 & 9.84 & 64.83 & 85.10 \\
\hline & 0.693 & 1.0892 & 0.443 & 27.80 & 9.88 & 62.42 & 84.90 \\
\hline & 0.734 & 1.0904 & 0.454 & 26.87 & 9.92 & 63.25 & 85.30 \\
\hline & Mean & 1.0901 & 0.449 & 26.36 & 9.87 & 63.81 & 85.10 \\
\hline & CV (\%) & 0.197 & 3.94 & 3.21 & 3.88 & 1.84 & 0.210 \\
\hline & $\mathrm{P}$ value & NS $(P>0.05)$ & NS $(P>0.05)$ & $L \quad(P<0.05)$ & NS $(P>0.05)$ & $L \quad(P<0.05)$ & NS $(P>0.05)$ \\
\hline & & \multicolumn{2}{|c|}{ Regression equation } & \multicolumn{2}{|c|}{ Requirement } & & $\mathrm{R}^{2}$ \\
\hline Yolk & & \multicolumn{2}{|c|}{$\hat{Y}=19.747+10.133 x$} & \multicolumn{2}{|c|}{0.572} & & 0.44 \\
\hline Albumen & & \multicolumn{2}{|c|}{$\hat{Y}=70.409-10.111 x$} & \multicolumn{2}{|c|}{0.734} & & 0.44 \\
\hline
\end{tabular}

SWSA - shell weight per unit surface area; NS - not significant; L - linear effect; CV - coefficient of variation. 
combinations of 17 and 0.57 and 17 and $0.64 \%$. On the other hand, Jordão Filho et al. (2006) recorded no effect from the levels of total methionine + cystine on yolk, shell and albumen percentages for brown-eggs laying hens at 20 to 44 weeks of age. Rodrigues et al. (1996) and Novak et al. (2004) also reported that the increase in methionine + cystine levels in the diet did not change the quality of eggshell. These data were reinforced by Silva et al. (2006), who found that shell quality and specific gravity were not affected by different levels of protein and sulfur amino acids.

However, Mendonça Junior \& Lima (1999) obtained decrease in percentage and shell thickness as the levels of methionine + cystine were increased in the diet. The authors justify this effect by the fact that methionine is an important factor to control the egg size, because as the amino acid level in the diet increases, there is a consequent increase in egg size due to the higher yolk deposition. This was observed in this study, although shell percentage did not change.

The highest percentage of yolk, due to the increased levels of digestible methionine + cystine, can be related to formation of choline from methionine added to phospholipids to form the lipoproteins of yolk.

According to Rostagno et al. (2005), the choline requirement for laying hens under production would be $20 \mathrm{mg} / \mathrm{bird} / \mathrm{day}$. The lipid content of yolk is continuously produced in the liver and transported to the ovary. It is important to highlight that the highest synthesis of protein for albumen occurs in the magnum, which is secreted almost in three hours (Novak et al., 2004). According to these authors, changes in the amino acid concentration in the blood cause major effects on the rate of the synthesis of nutrients in magnum than in the liver, due to their ingestion based on diet.
Thus, the protein synthesis in the magnum tissue can be affected by some changes in the concentration of amino acids in the blood. However, the increased digestible methionine + cystine intake found in this study did not improve albumen percentage, although it increased the production of albumen, which can be explained by the increase in egg weight.

There was no effect $(\mathrm{P}>0.05)$ of the studied digestible methionine + cystine levels on the initial and final weights and on weight gain of hens (Table 6).

On the other hand, Jordão Filho et al. (2006) recorded a quadratic effect on the final live weight of the birds, with a maximum level of $0.77 \%$ total methionine + cystine, while the weight gain increased linearly with the increased levels of these amino acids in the diet. The results mentioned are contrary to those recoded by Togashi et al. (2002) and Bunchasak \& Silapasorn (2005), who did not find any effect of methionine + cystine levels in the diet on weight gain for egg layers; however, Bunchasak \& Silapasorn (2005) observed some increase in abdominal fat with higher levels of methionine.

Sá et al. (2007) did not record any influence of methionine + cystine levels among bird strains on weight gain, although they observed that light birds had a gain of $132 \mathrm{~g}$, while the semi-heavy ones had a loss of $551 \mathrm{~g}$, from 34 to 50 weeks of age.

The high value of coefficient of variation for weight gain as well as the standard deviation for the evaluated treatments $(204.21 ; 144.41 ; 100.46 ; 181.80$ and $156.55 \mathrm{~g}$, respectively), with average standard deviation of $160.27 \mathrm{~g}$, explain the data dispersion and the results obtained for this variable.

Table 6 - Weight gain of hens from 50 to 66 weeks of age fed diets with different levels of methionine + digestible cystine

\begin{tabular}{cccc}
\hline Digestible met + cys levels (\%) & Initial weight (g/bird) & Final weight (g/bird) & Weight gain (g/bird) \\
\hline 0.572 & 1836.50 & 2065.42 & 228.92 \\
0.613 & 1865.83 & 2147.83 & 282.00 \\
0.653 & 1920.00 & 2084.50 & 164.00 \\
0.693 & 1861.33 & 2151.21 & 289.87 \\
0.734 & 1902.67 & 2060.50 & 157.83 \\
Mean & 1877.27 & 2101.89 & 224.62 \\
CV(\%) & 4.42 & 6.01 & 71.84 \\
P value & NS (P>0.05) & NS (P>0.05) & NS (P>0.05) \\
\hline
\end{tabular}

NS - not significant; CV - coefficient of variation.

\section{Conclusions}

Based on the parameters of performance and quality of the studied eggs, the $0.572 \%$ level of digestible methionine + cystine is adequate to meet daily requirements for browneggs laying hens of the Shaver Brown strain at the end of the first production cycle.

\section{References}

AHMAD, H.A.; ROLAND, D.A.; BRYANT, M.M. Effects of increased light and added methionine on molted hens. Journal Applied Poultry Research, v.6, n.4, p.373-380, 1997.

AHMAD, H.A.; ROLAND, D.A. Effect of environmental temperature and total sulfur amino acids on performance and profitability of laying hens: An econometric approach. Journal Applied Poultry Research, v.12, n.4, p.476-482, 2003. 
BARBOSA, B.A.C.; SOARES, P.R.; ROSTAGNO, H.S. et al. Exigência nutricional de metionina+cistina para galinhas poedeiras de ovos brancos e marrons, no segundo ciclo de produção. Revista Brasileira de Zootecnia, v.28, n.3, p.526-533, 1999.

BRAKE, J.; THAXTON, P.; GARLICH, J.D. et al. Comparison of fortified group corn and pullet grower feeding regimes during a forced molt on subsequent layer performance. Poultry Science, v.58, n.4, p.785-790, 1979.

BRUMANO, G.; GOMES, P.C.; DONZELE, J.L.; et al. Níveis de metionina+cisteína digestíveis em rações para poedeiras leves, no período de 42 a 58 semanas de idade. Revista Brasileira de Zootecnia, v.39, n.9, p.1984-1992, 2010.

BUNCHASAK, C.; SILAPASORN, T. Effects of adding methionine in low-protein diet on production performance, reproductive organs and chemical liver composition of laying hens under tropical conditions. International Journal of Poultry Science, v.4, n.5, p.301-308, 2005. (Asian Network for Scientific Information, 2005.)

CARVALHO, D.C.O.; ALBINO, L.F.T.; ROSTAGNO, H.S. et al. Biodisponibilidade de fontes de metionina para poedeiras leves na fase de produção mantidas em ambiente de alta temperatura. Revista Brasileira de Zootecnia, v.38, n.12, p.2383-2388, 2009.

CUPERTINO, E.S.; GOMES. P.C.; ROSTAGNO, H.S. et al. Exigência nutricional de metionina+cistina digestíveis para galinhas poedeiras de 54 a 70 semanas de idade. Revista Brasileira de Zootecnia, v.38, n.7, p.1238-1246, 2009.

FRASER, A.C.; BAIN, M.M; SOLOMON, S.E. Organic protein matrix morphology and distribuition in the palisade layer of eggshells sampled at selected periods during lay. British Poultry Science, v.39, p.225-228, 1998. (Abstr.).

GOULART, C.C. Exigência nutricional de lisina para poedeiras leves e semipesadas. 1997. 51f. Dissertação (Mestrado em Zootecnia) - Universidade Federal de Viçosa, Viçosa, MG.

HARMS, R.H. Influence of protein level in the resting diet upon performance of force rested hens. Poultry Science, v.62, n.2, p.273-276, 1983.

HARMS, R.H.; RUSSEL, G.B. The influence of methionine on commercial laying hens. Journal of Applied Poultry Research, v.7, n.1, p.45-52, 1998.

HARMS, R.H.; RUSSELL, G.B. Performance of commercial laying hens fed diets with various levels of methionine. Journal Applied Poultry Research, v.12, p.449-455, 2003.

HAUGH, R.R. The Haugh Unit for measuring egg quality. United States Egg and Poultry Magazine, v.4, p.552, 1937.

JORDÃO FILHO, J.; SILVA, J.H.V.; SILVA, E.L. et al. Exigências nutricionais de metionina+cistina para poedeiras semipesadas do início de produção até o pico de postura. Revista Brasileira de Zootecnia, v.35, n.3, p.1063-1069, 2006 (supl.).

JUNQUEIRA, O.M.; LAURENTIZ, A.C.; FILARDI, R.S. et al. Effects of energy and protein levels on egg quality and performance of laying hens at early second production cycle. Journal Applied Poultry Science, v.15, n.1, p.110-115, 2006.

KOELKEBECK, K.W.; BAKER, D.H.; HAY, Y. et al. Effect of excess lysine, methionine, threonine or tryptophan on production performance of laying hens. Poultry Science, v.70, n.7, p.1651-1653, 1991.

KOELKEBECK, K.W.; PARSONS, C.M.; LEEPER, R.W. et al. Effect of supplementation of a low-protein corn molt diet with amino acids on early postmolt laying hen performance. Poultry Science, v.72, n.8, p.1528-1536, 1993.

LEMME, A. La efectividade biológica de la metionina hidroxi análoga es menor que la DL-metionina-base fisiológica. Amino News TM, v.2, n.2, p.7-10, 2001.

MENDONÇA JUNIOR, C.X.; LIMA, F.R. Efeito dos níveis de proteína e de metionina da dieta sobre o desempenho de galinhas poedeiras após a muda forçada. Brazilian Journal of Veterinary Research and Animal Science, v.36, n.6, 1999.
NATIONAL RESEARCH COUNCIL - NRC. Nutrient requirements of poultry. 9.ed. Washington, D.C.: National Academy of Sciences, 1994. 155p.

NARVÁEZ-SOLARTE, W.; ROSTAGNO, H.S.; SOARES, P.R. et al. Nutritional requirements in Methionine + Cystine for whiteegg laying hens during the first cycle of production. International Journal of Poultry Science, v.4, n.12, p.965-968, 2005.

NOVAK, C.L.; YAKOUT, H.S.; SCHEIDELER, S. et al. The combined effects of dietary lysine and total sulfur amino acid level on egg production parameters and egg components in dekalb delta laying hens. Poultry Science, v.83, n.6, p.977-984, 2004.

PAVAN, A.C.; MÓRI, C.; GARCIA, E.A. et al. Níveis de proteína bruta e de aminoácidos sulfurados totais sobre o desempenho, a qualidade dos ovos e a excreção de nitrogênio de poedeiras de ovos marrons. Revista Brasileira de Zootecnia, v.34, n.2, p.568-574, 2005.

PINTO, R.; FERREIRA, A.S.; LOPES, D.J. et al. Exigência de metionina mais cistina e de lisina para codornas japonesas na fase de crescimento e de postura. Revista Brasileira de Zootecnia, v.32, n.5, p.1174-1181, 2003.

RODRIGUES, P.B.; BERTECHINI, A.G.; OLIVEIRA, B.L. et al Fatores nutricionais que influenciam a qualidade do ovo no segundo ciclo de produção e níveis de aminoácidos sulfurosos totais. Revista Brasileira de Zootecnia, v.25, n.2, p.249-260, 1996

ROSTAGNO, H.S.; ALBINO, L.F.T.; DONZELE, J.L. et al. Tabelas brasileiras para suínos e aves: Composição de alimentos e exigências nutricionais. 2.ed. Viçosa, MG: Universidade Federal de Viçosa, 2005. 186p.

SÁ, L.M.; GOMES, P.C.; ALBINO, L.F.T. et al. Exigência nutricional de metionina+cistina digestível para galinhas poedeiras no período de 34 a 50 semanas de idade. Revista Brasileira de Zootecnia, v.36, n.6, p.1837-1845, 2007.

SAFAA, H.M.; SERRANO, M.P.; VALENCIA, D.G. et al. Effects of the levels of methionine, linoleic acid, and added fat in the diet on productive performance and egg quality of Brown laying hens in the late phase of production. Poultry Science, v.87, n.10, p.1595-1602, 2008.

SAKOMURA, N.K.; ROSTAGNO, H.S. Métodos de pesquisa em nutrição de monogástricos. Jaboticabal: Funep, 2007. 283p.

SILVA, E.L.; SILVA, J.H.V.; JORDÃO FILHO, J. et al. Redução dos níveis protéicos e suplementação com metionina e lisina em rações para poedeiras leves. Revista Brasileira de Zootecnia, v.35, n.2, p.491-496, 2006.

SNYDER, E.S. Eggs, the production, the identification and retention of quality in eggs. Guelph: Ontario Agricultural College, 1961. 90p.

SOHAIL, S.S.; BRYANT, M.M.; ROLAND, D.A. Influence of supplemental lysine, isoleusine, threonine, tryptophan and total sulfur amino acids on egg weight of Hy-line W36 hens. Poultry Science, v.81, n.7, p.1038-1044, 2002.

STRINGHINI, J.H.; FILHO, R.M.J.; PEDROSO, A.A. et al. Nutrição no período pré-postura, pico e pós-pico de poedeiras comerciais. In: CONFERÊNCIA APINCO 2005 DE CIÊNCIA E TECNOLOGIA AVÍCOLAS, 2005, Santos. Anais... Santos: Fundação APINCO de Ciência e Tecnologia Avícolas, 2005. v.2, p.171-189.

TOGASHI, C.K.; FONSECA, J.B.; SOARES, R.T.R.N. et al. Determinação de níveis de metionina+cistina para poedeiras semipesadas alimentadas com rações contendo levedura seca. Revista Brasileira de Zootecnia, v.31, n.3, p.1426-433, 2002 (supl.)

VARELA, E.V. Níveis nutricionais de metionina + cistina digestíveis em poedeiras Hy-Line W36 com base no conceito de proteína ideal. 2009. 34f. Dissertação (Mestrado em Zootecnia) - Universidade Estadual de Maringá, Maringá. 